\title{
Uji Viabilitas dan Vigor Benih Padi (Oryza sativa, L.) selama Penyimpanan pada Tingkat Kadar Air yang Berbeda
}

Anna Tefa ${ }^{\text {a }}$

${ }^{a}$ Fakultas Pertanian, Universitas Timor, Kefamenanu, TTU - NTT, Indonesia.

\section{Article Info}

\section{Article history:}

Received 4 Desember 2016

Received in revised form 20 Maret 2017

Accepted 9 Juni 2017

\section{Keywords:}

Kadar Air

Padi

Periode Simpan

Viabilitas

Vigor

\section{Abstrak}

Padi merupakan tanaman pangan utama bagi sebagian besar penduduk indonesia. Budidaya padi memerlukan benih yang memiliki vigo dan viabilitas tinggi untuk meningkatkan produksi. Kadar air benih selama penyimpanan merupakan salah satu indikator vigor da ya simpan yang menggambarkan kemampuan benih untuk dapat disimpan dalam waktu lama. Tujuan penelitian ini adalah mengetahui kadar air benih yang optimum selama penyimpanan yang dapat meningkatkan viabilitas dan vigor benih padi. Penelitian ini menggunakan rancangan acak lengkap (RAL) pola faktorial. Faktor pertama adalah kadar air benih yang terdiri atas 4 perlakuan yaitu $\mathrm{k}_{0}\left(20 \%\right.$ sebagai kontrol), $\mathrm{k}_{1}(14 \%)$, $\mathrm{k}_{2}(12 \%), \mathrm{k}_{3}(10 \%)$. Faktor kedua adalah periode simpan yang terdiri atas 4 perlakuan yaitu $0,1,2$, dan 3 bulan. Hasil penelitian menunjukkan bahwa kadar air benih $14 \%$ memberikan viabilitas benih yang tinggi pada penyimpanan 1 bulan pada peubah potensi tumbuh maksimum $100 \%$, daya berkecambah $84 \%$ pada periode simpan 3 bulan. Kadar air $14 \%$ juga meningkatkan vigor benih pada peubah inkes vigor $0,89 \%$ pada periode simpan 3 bulan, kecepatan tumbuh 12,68\%/etmal pada periode simpan 3 bulan, keserempakan tumbuh $1,46 \%$ dan $1,57 \%$ pada periode simpan 2 dan 3 bulan serta berat kering kecambah normal $0,27 \mathrm{~g}$ dan $0,24 \mathrm{~g}$ pada periode simpan 2 dan 3 bulan (C2017 dipublikasikan oleh Savana Cendana.

\section{Pendahuluan}

Padi (Oryza sativa, L) merupakan tanaman penghasil beras yang menjadi sumber pangan utama bagi sebagian besar penduduk Indonesia. Peningkatan pertumbuhan jumlah penduduk Indonesia berkaitan dengan ketersediaan pangan terutama beras. Kementrian Pertanian menyebutkan bahwa perkiraan kebutuhan dan ketersediaan beras nasional yaitu 139,15 kg/tahun dengan perkiraan jumlah penduduk 252 juta jiwa (Deptan, 2014).

Ketersediaan benih bermutu menyebabkan tanaman yang dihasilkan memiliki kualitas yang baik dan tinggi tingkat produksinya. Benih merupakan bahan tanam yang menentukan awal keberhasilan suatu proses produksi. Sebelum menjadi tanaman, benih harus melalui proses perkecambahan terlebih dahulu. Beberapa hal yang dapat menyebabkan turunnya mutu benih adalah kadar air yang tidak tepat selama periode penyimpanan. Hal ini akan meningkatkan laju deteriorasi, sehingga viabilitas dan vigor benih cepat menurun (Hendarto, 2005).

Penurunan mutu dan kerusakan benih selama penyimpanan tidak dapa dihentikan akan tetapi dapat diperlambat dengan mengatur kondisi penyimpanan. Kadar air benih merupakan faktor utama yang menentukan daya simpan benih Kerusakan benih selama penyimpanan sebagian besar dipengaruhi oleh kandungan air di dalam benih (Justice dan Bass, 2002).

Kadar air benih yang tinggi dapat meningkatkan laju kemunduran benih pada tempat penyimpanan. Laju kemunduran benih dapat diperlambat dengan cara kadar air benih harus dikurangi sampai kadar air benih optimum (Tuwu $e$ al. 2012). Kadar air benih yang melebihi batas kritikalnya akan menyebabkan kerusakan protein, diduga terbentuknya radikal bebas. Menurut Tatipata (2008), oksidasi gugus radikal bebas menghasilkan hidroperoksida yang dapat bereaks dengan protein sehingga aktivitasnya menurun. Hasil penelitian Dewi dan Sumarjan (2013) menunjukkan bahwa benih padi yang disimpan dalam kantong plastik bagor selama 0-6 bulan mengalami peningkatan kadar air pada 5 bulan simpan yaitu $12,11 \%$ dan 6 bulan simpan $12,21 \%$.

Penyimpanan benih padi dilakukan segera setelah tanaman selesai dipanen dan melalui proses pengeringan untuk mengurangi kadar air benih. Metode penyimpanan benih ada dua macam yaitu penyimpanan secara tradisional dan modern. Penyimpanan secara tradisional diantaranya adalah dengan menyimpan benih dalam kantong plastik, lumbung sederhana, keranjang yang terbuat dari daun lontar atau benih-benih diikat kecil-kecil dan diletakkan diatas perapian (Dewi dan Sumarjan, 2013).

Raganatha et el. (2014), menyatakan bahwa tingkat vigor awal benih tidak dapat dipertahankan, dan benih yang disimpan selalu mengalami proses kemunduran mutunya secara kronologis selama penyimpanan. Sifat kemunduran ini tidak dapat dicegah dan tidak dapat balik atau diperbaiki secara sempurna Laju kemunduran mutu benih hanya dapat diperkecil dengan melakukan pengolahan dan penyimpanan secara baik. Berapa lama benih dapat disimpan sangat bergantung pada kondisi benih terutama kadar air benih dan lingkungan tempatnya menyimpan.

Kemunduran benih merupakan proses penurunan mutu secara berangsuranngsur dan kumulatif serta tidak dapat balik (irreversible) akibat perubahan fisisologis yang disebabkan oleh faktor dalam. Proses penuaan atau mundurnya vigor secara fisiologis ditandai dengan penurunan daya berkecambah, peningkatan jumlah kecambah abnormal, penurunan pemunculan kecambah di lapangan (field emergence), terhambatnya pertumbuhan dan perkembangan tanaman, meningkatnya kepekaan terhadap lingkungan yang ekstrim yang akhirnya dapat menurunkan produksi tanaman (Copeland dan Donald, 1985).

Berdasarkan hal-hal tersebut di atas maka dipandang perlu untuk melakukan penelitian guna mengetahui sampai sejauh mana pengaruh kadar air benih dan lama penyimpanan terhadap viabilitas dan vigor benih padi. Tujuan penelitian in adalah mengetahui kadar air benih yang optimum selama penyimpanan yang dapat meningkatkan viabilitas dan vigor benih padi.

\section{Metode}

Percobaan dilaksanakan di Laboratorium Fakultas Pertanian Universitas Timor, Kefamenanu, mulai bulan Juli sampai dengan Oktober 2016. Rancangan percobaan yang digunakan adalah Rancangan Acak Lengkap (RAL) pola faktorial. Faktor pertama adalah Kadar air $(\mathrm{K})$ yang terdiri atas 4 perlakuan yaitu $\mathrm{k}_{0}=20 \%$ (sebagai kontrol), $\mathrm{k}_{1}=14 \%, \mathrm{k}_{2}=12 \%$ dan $\mathrm{k}_{3}=10 \%$. Faktor kedua adalah periode simpan (S) yang terdiri atas 3 perlakuan yaitu $0,1,2$ dan 3 bulan. Percobaan ini diulang 4 kali, masing-masing ulangan ditanam 25 butir benih. Data yang diperoleh dianalisis dengan program statistical analysis system (SAS). Perlakuan yang berpengaruh nyata diuji lanjut dengan DMRT taraf $\alpha=0,05$ sesuai petunjuk Mattjik dan Sumertajaya (2006).

Pengujian di Laboratorium menggunakan metode uji kertas digulung didirikan dalam plastik (UKDdP). Peubah viabilitas dan vigor benih padi yang diamati yaitu :

a. Potensi Tumbuh Maksimum (PTM) (\%) yang tumbuh normal maupun abnormal pada 7 HST (hari setelah tanam). Potensi tumbuh maksimum dihitung dengan rumus:

$$
\operatorname{PTM}(\%)=\frac{\Sigma \text { benih yang tumbuh }}{\Sigma \text { benih yang ditanam }} \times 100 \%
$$

b. Daya Berkecambah (DB) $(\%)$

Daya berkecambah diperoleh dengan menghitung jumlah benih yang berkecambah normal pada 5 dan 7 HST. Daya berkecambah benih dihitung dengan rumus:

$$
D B(\%)=\frac{\Sigma K N \text { Hitungan } I+\Sigma K N \text { Hitung } I I}{\sum \text { benih yang ditanam }} \times 100
$$

Keterangan:

$\mathrm{KN}=$ Kecambah Normal

c. Kecepatan Tumbuh $\left(\mathrm{K}_{\mathrm{CT}}\right)(\%$ letmal $)$

Kecepatan tumbuh dihitung setiap hari selama 7 hari pada benih yang tumbuh normal. Kecepatan tumbuh dihitung dengan rumus:

$$
K C T=\left(\% \frac{K N}{\text { etmal }}\right)=\sum_{0}^{t n} \frac{N}{t}
$$

Keterangan:

$$
\begin{array}{ll}
\mathrm{t} & =\text { waktu pengamatan ke- } \mathrm{i} \\
\mathrm{N} & =\text { persentase kecambah normal setiap waktu pengamatan } \\
\mathrm{tn} & =\text { waktu akhir pengamatan (hari ke } 7 \text { ) }
\end{array}
$$$$
1 \text { etmal }=1 \text { hari }
$$

\section{d. Berat Kering Kecambah Normal (BKKN) (g)}

Berat kering kecambah diperoleh dengan menimbang kecambah normal pada 7 HST yang telah dikeringkan di dalam oven bersuhu $60^{\circ} \mathrm{C}$ selama 72 jam

e. Indeks vigor (IV) $(\%)$

Pengamatan indeks vigor dilakukan terhadap jumlah kecambah normal pada hitungan pertama (first count) yaitu pada hari ke-5 (ISTA, 2010).

$$
\text { IV }(\%)=\frac{\sum \text { kecambah normal pada hitungan pertama }}{\sum \text { benih yang ditanam }} \times 100 \%
$$

f. Keserempakan tumbuh $\left(\mathrm{K}_{\mathrm{ST}}\right)(\%)$

Keserempakan tumbuh dihitung berdasarkan persentase kecambah normal pada 6 HST. Pengamatan dilakukan terhadap jumlah bibit normal diantara hitungan pertama dan hitungan kedua. Pada benih padi pengamatan
Potensi tumbuh maksimum diperoleh dengan menghitung jumlah kecambah 
keserempakan tumbuh dilakukan pada hari ke-6. Keserempakan tumbuh dihitung dengan rumus:

$$
\mathrm{K}_{\mathrm{ST}}=\frac{\sum K N \text { hari } \mathrm{ke}-6}{\sum \text { benih } \text { yang ditanam }} \times 100 \%
$$

\section{Hasil dan Pembahasan}

Hasil analisis ragam menunjukkan bahwa interaksi perlakuan kadar air dan periode simpan berpengaruh nyata terhadap potensi tumbuh maksimum, indeks vigor, kecepatan tumbuh dan keserempakan tumbuh. Perlakuan kadar air berpengaruh nyata terhadap indeks vigor dan kecepatan tumbuh. Perlakuan periode simpan berpengaruh sangat nyata terhadap potensi tumbuh maksimum, daya berkecambah, indeks vigor, kecepatan tumbuh, keserempakan tumbuh dan berat kering kecambah normal (Tabel 1.).

Tabel 1. Analisis Ragam Pengaruh Perlakuan Kadar Air dan Periode Simpan terhadap Viabilitas dan Vigor Benih Padi.

\begin{tabular}{lcccc}
\hline \multirow{2}{*}{ Peubah Pengamatan } & \multicolumn{3}{c}{ Perlakuan dan Interaksinya } & \\
\cline { 2 - 4 } & $\begin{array}{c}\text { Kadar } \\
\text { Air }\end{array}$ & $\begin{array}{c}\text { Periode } \\
\text { Simpan }\end{array}$ & $\begin{array}{c}\text { Kadar Air X } \\
\text { Periode Simpan }\end{array}$ & KK $(\%)$ \\
\hline $\begin{array}{l}\text { Potensi Tumbuh } \\
\text { Maksimum }\end{array}$ & tn & $* *$ & $*$ & 5.35 \\
\hline Daya Berkecambah & tn & $* *$ & tn & 19.13 \\
\hline Indeks Vigor & $*$ & $* *$ & $*$ & 23.87 \\
\hline Kecepatan Tumbuh & $*$ & $* *$ & $*$ & 13.99 \\
\hline $\begin{array}{l}\text { Keserempakan } \\
\text { Tumbuh }\end{array}$ & tn & $* *$ & tn & 12.40 \\
\hline $\begin{array}{l}\text { Berat Kering } \\
\text { Kecambah Normal }\end{array}$ & tn & $* *$ & tn & 32.82 \\
\hline Keterangan : tn = tidak nyata, * $=$ nyata, $* *=$ sangat nyata, KK $=$ Koefisien keragaman &
\end{tabular}

\subsection{Viabilitas}

Viabilitas adalah daya hidup benih yang dapat ditunjukkan oleh proses pertumbuhan benih. Parameter viabilitas yang diamati dalam penelitian ini yaitu peubah daya berkecambah (DB) dan potensi tumbuh maksimum (PTM) yang disajikan pada Tabel 2 dan 3 .

Berdasarkan hasil analisis pada Tabel 2 dan 3 menunjukkan perlakuan kadar air $14 \%$ meningkatkan potensi tumbuh maksimum sebesar $100 \%$ sedangkan perlakuan kadar air $20 \%$, potensi tumbuh maksimum hanya mencapai $93.00 \%$ pada periode simpan 1 bulan (Tabel 2.). Benih yang disimpan pada periode simpan 3 bulan menunjukkan daya berkecambah $84.00 \%$ dibandingkan benih yang tidak disimpan ( 0 bulan) yang hanya menghasilkan daya berkecambah $8.50 \%$ (Tabel 3.).

Tabel 2. Pengaruh Interaksi Perlakuan Kadar Air dan Periode Simpan terhadap Potensi Tumbuh Maksimum (\%) Benih Padi.

\begin{tabular}{ccccc}
\hline \multirow{2}{*}{ Kadar Air } & \multicolumn{4}{c}{ Periode Simpan (Bulan) } \\
\cline { 2 - 5 } & 0 & 1 & 2 & 3 \\
\hline $20 \%$ & $89.60 \mathrm{bA}$ & $93.00 \mathrm{aB}$ & $92.20 \mathrm{aA}$ & $99.20 \mathrm{aA}$ \\
$14 \%$ & $93.00 \mathrm{bA}$ & $100.00 \mathrm{aA}$ & $96.00 \mathrm{abA}$ & $98.00 \mathrm{abA}$ \\
$12 \%$ & $87.00 \mathrm{bA}$ & $100.00 \mathrm{aA}$ & $99.00 \mathrm{aA}$ & $99.00 \mathrm{aA}$ \\
$10 \%$ & $92.00 \mathrm{aA}$ & $100.00 \mathrm{aA}$ & $93.00 \mathrm{aA}$ & $98.67 \mathrm{aA}$ \\
\hline Keterangan : & Angka & yang diikuti huruf & yang sama menunjukkan hasil yang tidak berbeda nyata \\
\multicolumn{4}{c}{ berdasarkan DMRT pada $\alpha=5 \%$. Huruf kecil ke samping (dalam satu baris) menunjukkan } \\
pengaruh perlakuan periode simpan sedangkan huruf kapital ke bawah (dalam satu kolom) \\
menunjukkan pengaruh perlakuan kadar air benih.
\end{tabular}

Tabel 3. Pengaruh Perlakuan Periode Simpan terhadap Daya Berkecambah (\%) Benih Padi.

\begin{tabular}{cccccc}
\hline \multirow{2}{*}{ Kadar Air } & \multicolumn{4}{c}{ Periode Simpan (Bulan) } & \multirow{2}{*}{ Rerata } \\
\cline { 2 - 5 } & 0 & 1 & 2 & 3 & \\
\hline $20 \%$ & 8.80 & 60.80 & 69.60 & 83.20 & 55.60 \\
$14 \%$ & 8.00 & 67.00 & 70.00 & 75.00 & 55.00 \\
$12 \%$ & 8.00 & 76.00 & 70.00 & 93.00 & 61.75 \\
$10 \%$ & 9.33 & 65.33 & 69.33 & 85.33 & 57.33 \\
\hline Rerata & $8.50 \mathrm{c}$ & $67.00 \mathrm{~b}$ & $69.75 \mathrm{~b}$ & $84.00 \mathrm{a}$ \\
\hline \multicolumn{4}{l}{ Keterangan : Angka yang diikuti huruf yang sama pada baris yang sama menunjukkan hasil yang tidak } \\
\multicolumn{4}{l}{ berbeda nyata berdasarkan DMRT pada $\alpha=5 \%}$.
\end{tabular}

\subsection{Vigor}

Vigor merupakan sejumlah sifat-sifat benih yang mengindikasikan pertumbuhan dan perkembangan kecambah yang normal, cepat dan seragam pada kisaran kondisi lapang yang optimum maupun sub optimum (Ilyas, 2015). Peubah vigor yang diamati dalam penelitian ini yaitu indeks vigor (IV) (\%), kecepatan tumbuh (Kct) (\%/etmal), keserempakan tumbuh (Kst) (\%) dan berat kering kecambah normal (BKKN) (g) yang terdapat pada Tabel 4, 5, 6 dan 7.

Perlakuan interaksi perlakuan kadar air 14\% dan periode simpan 3 bulan meningkatkan indeks vigor $0.89 \%$, sedangkan interaksi perlakuan kadar air $12 \%$ dan $20 \%$ pada periode simpan 0 bulan menurunkan indeks vigor $0,00 \%$ (Tabel 4). Interaksi perlakuan kadar air 14\% dan periode simpan 3 bulan meningkatkan kecepatan tumbuh $12,68 \%$ /etmal, sedangkan interaksi perlakuan kadar air $10 \%$ pada periode simpan 3 bulan 9,73\%/etmal (Tabel 5.).

Perlakuan penyimpanan meningkatkan keserempakan tumbuh pada periode simpan 2 dan 3 bulan yaitu $1,46 \%$ dan $1,57 \%$, sedangkan perlakuan periode simpan 0 dan 1 bulan, keserempakan tumbuh hanya $0,75 \%$ dan 1,14\% (Tabel 6.).
Perlakuan penyimpanan meningkatkan berat kering kecambah normal pada periode simpan 2 dan 3 bulan yaitu $0,27 \mathrm{~g}$ dan $0,24 \mathrm{~g}$, sedangkan perlakuan periode simpan 0 dan 1 bulan berat kering kecambah normal hanya sebesar 0,08 $\mathrm{g}$ dan $0,18 \mathrm{~g}$ (Tabel 7.).

Tabel 4. Pengaruh Interaksi Kadar Air dan Periode Simpan terhadap Indeks Vigor (\%) Benih Padi.

\begin{tabular}{ccccc}
\hline \multirow{2}{*}{ Kadar Air } & \multicolumn{5}{c}{ Periode Simpan (Bulan) } \\
\cline { 2 - 5 } & 0 & 1 & 2 & 3 \\
\hline $20 \%$ & $0.00 \mathrm{bB}$ & $0.80 \mathrm{aAB}$ & $0.70 \mathrm{aB}$ & $0.83 \mathrm{aA}$ \\
$14 \%$ & $0.53 \mathrm{bA}$ & $0.70 \mathrm{abB}$ & $0.89 \mathrm{aA}$ & $0.89 \mathrm{aA}$ \\
$12 \%$ & $0.00 \mathrm{cB}$ & $0.89 \mathrm{aA}$ & $0.70 \mathrm{bB}$ & $0.70 \mathrm{bA}$ \\
$10 \%$ & $0.47 \mathrm{aA}$ & $0.70 \mathrm{abB}$ & $0.78 \mathrm{aAB}$ & $0.87 \mathrm{aA}$ \\
\hline
\end{tabular}

Angka yang diikuti huruf yang sama menunjukkan hasil yang tidak berbeda nyata berdasarkan DMRT pada $\alpha=5 \%$. Huruf kecil ke samping (dalam satu baris) menunjukkan pengaruh perlakuan periode simpan sedangkan huruf kapital ke bawah (dalam satu kolom)
menunjukkan pengaruh perlakuan kadar air benih. Data yang digunakan adalah data yang menunjukkan pengaruh perlak
sudah ditransformasi log $x+1$.

Tabel 5. Pengaruh Interaksi Perlakuan Kadar Air dan Periode Simpan terhadap Kecepatan Tumbuh (\%/Etmal) Benih Padi.

\begin{tabular}{ccccc}
\hline \multirow{2}{*}{ Kadar Air } & \multicolumn{4}{c}{ Periode Simpan (Bulan) } \\
\cline { 2 - 5 } & 0 & 1 & 2 & 3 \\
\hline $20 \%$ & $1.26 \mathrm{cA}$ & $14.16 \mathrm{aA}$ & $10.69 \mathrm{bA}$ & $11.62 \mathrm{bAB}$ \\
$14 \%$ & $1.14 \mathrm{cA}$ & $14.09 \mathrm{aA}$ & $10.88 \mathrm{bA}$ & $12.68 \mathrm{abA}$ \\
$12 \%$ & $1.14 \mathrm{cA}$ & $14.07 \mathrm{aA}$ & $10.95 \mathrm{bA}$ & $10.99 \mathrm{bAB}$ \\
$10 \%$ & $1.33 \mathrm{cA}$ & $14.41 \mathrm{aA}$ & $10.38 \mathrm{bA}$ & $9.73 \mathrm{bB}$ \\
\hline Keterangan : Angka yang diikuti huruf yang sama menunjukkan hasil yang tidak berbeda nyata
\end{tabular}
berdasarkan DMRT pada $\alpha=5 \%$. Huruf kecil ke samping (dalam satu baris) menunjukkan pengaruh perlakuan periode simpan sedangkan huruf kapital ke bawah (dalam satu kolom) menunjukkan pengaruh perlakuan kadar air benih.

Tabel 6. Pengaruh Periode Simpan terhadap Keserempakan Tumbuh (\%) Benih Padi.

\begin{tabular}{cccccc}
\multicolumn{5}{c}{ Kadar Air } & \multicolumn{5}{c}{ Periode Simpan (Bulan) } & \multirow{2}{*}{ Rerata } \\
\cline { 2 - 5 } & 0 & 1 & 2 & 3 & \\
\hline $20 \%$ & 0.70 & 1.14 & 1.45 & 1.63 & 1.23 \\
$14 \%$ & 0.70 & 1.24 & 1.51 & 1.64 & 1.27 \\
$12 \%$ & 0.83 & 1.04 & 1.54 & 1.42 & 1.21 \\
$10 \%$ & 0.78 & 1.17 & 1.32 & 1.58 & 1.21 \\
\hline Rerata & $0.75 \mathrm{c}$ & $1.14 \mathrm{~b}$ & $1.46 \mathrm{a}$ & $1.57 \mathrm{a}$ & \\
\hline Keterangan : & Angka yang diikuti huruf yang sama pada baris yang sama menunjukkan hasil yang tidak \\
& berbeda nyata berdasarkan DMRT pada & $\alpha=5 \%$. Data yang digunakan adalah data yang \\
& sudah ditransformasi log $x+1$.
\end{tabular}

Tabel 7. Pengaruh Periode Simpan terhadap Berat Kering Kecambah Normal (g) Benih Padi.

\begin{tabular}{cccccc}
\hline \multirow{2}{*}{ Kadar Air } & \multicolumn{4}{c}{ Periode Simpan (Bulan) } & \multirow{2}{*}{ Rerata } \\
\cline { 2 - 5 } & 0 & 1 & 2 & 3 & \\
\hline $20 \%$ & 0.08 & 0.16 & 0.28 & 0.21 & 0.18 \\
$14 \%$ & 0.06 & 0.19 & 0.31 & 0.27 & 0.21 \\
$12 \%$ & 0.07 & 0.17 & 0.23 & 0.26 & 0.18 \\
$10 \%$ & 0.09 & 0.19 & 0.23 & 0.23 & 0.19 \\
\hline Rerata & $0.08 \mathrm{c}$ & $0.18 \mathrm{~b}$ & $0.27 \mathrm{a}$ & $0.24 \mathrm{a}$ &
\end{tabular}

Keterangan : Angka yang diikuti huruf yang sama pada baris yang sama menunjukkan hasil yang tidak berbeda nyata berdasarkan DMRT pada $\alpha=5 \%$.

\subsection{Pembahasan}

Berdasarkan hasil penelitian, kadar air yang tinggi menurunkan viabilitas dan vigor benih padi selama penyimpanan. Menurut Sutopo (2002), kadar air benih yang tinggi selama penyimpanan menyebabkan meningkatnya reaksi enzimatis yang memacu ke arah perombakan senyawa makro terutama karbohidrat. Akibatnya perombakan cadangan makanan dalam benih pada awa perkecambahan menjadi semakin besar, sehingga terjadi degradasi karbohidrat. Benih yang kekurangan karbohidrat akan kehilangan energi untuk berkecambah Kadar air 20\% dapat dinyatakan bahwa kadar air tersebut berat dan kadar air $20 \%$ tidak tahan terhadap hama dan penyakit (Kastanja, 2007).

Perkecambahan benih merupakan suatu rangkaian perubahan-perubahan morfologi, fisiologi dan biokimia. Copeland \& Mc. Donald (2001) menyatakan bahwa perkecambahan benih, secara fisiologis adalah muncul dan berkembangnya struktur-struktur penting dari embrio benih sampai dengan akar menembus kulit benih.

Benih padi merupakan material yang higroskopis artinya mudah menyerap air. Kadar air di dalam benih padi sangat tergantung pada kelembaban dan temperatur udara di dalam ruang penyimpanan. Jika tekanan uap air di dalam benih padi lebih besar daripada tekanan uap air yang ada diudara, maka uap air akan menerobos keluar dari benih padi dan sebaliknya. Kadar air yang terlalu tinggi selama penyimpanan menyebabkan terkurasnya bahan cadangan makanan di dalam benih padi akibat aktivitas respirasi yang terus meningkat (Mugnisjah, 1990).

Kadar air yang terlalu rendah akan menyebabkan kerusakan pada embrio (Mugnisjah, 1990). Menurut Agrawal (1980), benih ortodoks seperti padi yang disimpan pada kadar air $12-14 \%$ viabilitas benih menurun dengan cepat, 
disamping itu cendawan juga tumbuh dan berkembang serta merusak benih dengan pesat.

Kadar air awal penyimpanan meskipun rendah, penyimpanan terbuka menyebabkan kerusakan benih yang tinggi, menurunkan daya kecambah, dan daya simpan benih tidak bisa lama. Penyimpanan benih terbuka hanya dapat dilakukan untuk benih yang segera akan digunakan. Penyimpanan kedap udara selain menghambat kegiatan biologis benih, juga berfungsi menekan pengaruh kondisi lingkungan seperti suhu dan kelembapan, serta mengurangi tersedianya oksigen, kontaminasi hama, kutu, jamur, bakteri, dan kotoran. Kadar air awal sangat berpengaruh dalam mempertahankan kadar air benih selama penyimpanan karena semakin tinggi kadar air benih semakin tinggi pula laju deteriorasi benih (Kartono, 2004; Kuswanto, 2003).

Periode simpan benih padi yang dapat meningkatkan viabilitas dan vigor benih padi berdasarkan hasil penelitian ini adalah periode simpan 3 bulan. Benih padi yang baru dipanen pada umumnya mengalami dormansi walaupun embrio telah terbentuk sempurna dan kondisi lingkungan mendukung untuk berkecambah. Dormansi tersebut dapat dipecah jika benih mengalami penyimpanan kering yang disebut dengan after-ripening (Sutopo, 2002).

Fenomena after ripening yaitu dormansi yang terjadi pada benih padi dimana benih padi tidak mampu berkecambah ketika baru dipanen dan baru dapat berkecambah setelah melewati periode penyimpanan kering. Fenomena after ripening pada perkecambahan padi menyebabkan masalah tersendiri. Jika jangka waktu benih berkecambah cukup lama maka akan mengganggu proses pertumbuhan padi. Hasil penelitian Rahayu dan Widajati (2007) menunjukkan bahwa benih caisin pecah dormansinya setelah disimpan lebih dari 15 minggu. Wahyuni et al. (2004) menyatakan bahwa dormansi pada padi merupakan mekanisme alami untuk melindungi gabah dari berkecambah di lapangan sebelum tanaman dipanen pada kondisi basah atau tanaman rebah.

Periode after-ripening berbeda-beda pada setiap species dan varietas tanaman. Perbedaan tersebut mencerminkan adanya keragaman genetik sifat dormansi dari setiap spesies dan varietas tanaman tersebut. Varietas Ciherang yang digunakan dalam penelitian ini berumur pendek atau genjah (100-115 hari) tidak selalu memiliki periode after-ripening yang pendek. Dormansi akibat kebutuhan akan after-ripening ini dapat dipatahkan dengan perlakuan suhu tinggi, pengupasan kulit dan perendaman pada larutan kimia (Santika, 2006)

Tingginya nilai BKKN pada periode simpan 2 dan 3 bulan menunjukkan tingginya vigor benih (Justice dan Bass, 2002). Menurut Sadjad et al. (1999), kemampuan berkecambah suatu benih berhubungan dengan banyaknya cadangan makanan yang dikandungnya. Prawinata et al. (1992) menjelaskan benih yang memiliki vigor tinggi mampu menghasilkan berat kering kecambah normal yang tinggi pada kondisi optimum dan sub optimum.

\section{Simpulan}

Kadar air benih $14 \%$ memberikan viabilitas benih yang tinggi pada penyimpanan 1 bulan pada peubah potensi tumbuh maksimum $100 \%$, daya berkecambah $84 \%$ pada periode simpan 3 bulan. Kadar air $14 \%$ juga meningkatkan vigor benih pada peubah inkes vigor $0,89 \%$ pada periode simpan 3 bulan, kecepatan tumbuh 12,68\%/etmal pada periode simpan 3 bulan, keserempakan tumbuh $1,46 \%$ dan $1,57 \%$ pada periode simpan 2 dan 3 bulan serta berat kering kecambah normal $0,27 \mathrm{~g}$ dan $0,24 \mathrm{~g}$ pada periode simpan 2 dan 3 bulan.

\section{Pustaka}

Agrawal, R. L. 1980. Seed Technology. Oxford and IBH publishing Co., New Delhi- Bombay-Calcuta.

Copeland. L.O. dan M.B. Mc. Donald. 2001. "Principles of Seed Science and Technology". Burgess Publishing Company. New York. 369 p.

Deptan [Departemen Pertanian]. 2014. Rencana strategis Kementerian Pertanian. Departemen Pertanian Republik Indonesia.

Dewi, I. K., Sumarjan. 2013. Viabilitas dan Vigor Benih Padi (Oriza sativa, L) Varietas IR 64 Berdasarkan Variasi Tempat dan Lama Penyimpanan. Seminar Nasional FMIPA Undiksha III : 232-238.

Hendarto, K. 2005. Dasar-dasar Teknologi dan Sertifikasi Benih. Andi Offset : Yogyakarta.

International Seed Testing Association (ISTA). 2010. Seed Science and Technology. International rules for seed testing. Zurich: International Seed Testing Association.

Justice, O.L., Bass, L.N. 2002. Prinsip dan Praktek Penyimpanan Benih. PT Raja Grafido Persada; Jakarta

Kastanja, A.Y. 2007. Identifikasi Kadar Air Biji Jagung dan Tingkat Kerusakannya pada Tempat Penyimpanan. Jurnal Agroforestri Vol.II(1):2732.

Kartono. 2004. Teknik penyimpanan benih kedelai varietas wilis pada kadar air dan suhu penyimpanan yang berbeda. Buletin Teknik Pertanian 9:79-82.

Kuswanto, H. 2003. Teknologi pemrosesan, Pengemasan, dan penyimpanan Benih. Kanisius, Yogyakarta.

Mattjik, A.A., Sumertajaya, I.M. 2006. Perancangan Percobaan. IPB Pres; Bogor.

Mugnisjah, W.Q dan Setiawan. A. 1990. Pengantar Produksi Benih. Kanisius. Jakarta.

Prawinata W., S. Harran dan P. Tjndronegoro. 1992. Dasar-dasar fisiologi tumbuhan. Fakultas matematika dan Ilmu Alam.IPB Bogor. 247 hal.
Raganatha, I.N., Raka, I.G.N., Siadi, I.K. 2014. Daya Simpan Benih Tomat (Lycopersicum esculentum mill.) Hasil Beberapa Teknik ekstraksi. E-Jurnal Agroekoteknologi Tropika. Vol. 3(3):183-190.

Rahayu E., Widajati E. 2007. Pengaruh kemasan, kondisi ruang simpan dan periode simpan terhadap viabilitas benih Caisin (Brassica chinensis L). Bul. Agron. (35) (3) 191-196.

Sadjad S., Murniati E., Ilyas S. 1999. Parameter pengujian vigor benih dari komparatif ke simulatif. Grasindo dan PT Sang Hyang Seri: Jakarta.

Santika, A. 2006. Teknik Pengujian masa dormansi Benih padi (Oryza sativa, L) Bogor. Buletin Teknik Pertanian 11(2);67-71.

Sutopo, L. 2002. Teknologi Benih. Rajawali Press; Jakarta.

Tatipata, A. 2008. Pengaruh Kadar Air Awal, Kemasan dan Lama Simpan terhadap Protein Membran dalam Mitokondria Benih Kedelai. Bul. Agron. Vol. 36(1):8-16.

Tuwu, E.R., Sutariati, G.A.K., Suaib. 2012. Pengaruh kadar air awal dan Jenis kemasan terhadap Vigor benih Sorgum (Sorgum bicolor, L) dalam Enam Bulan Masa Simpan. Berkala Penelitian Agronomi. Vol. 1(2):184-193.

Wahyuni, S., T. S. Kadir., U. S. Nugraha. 2004. Karakterisasi Dormansi dan Metode Efektif untuk pematahan Dormansi benih plasma nutfah padi. Badan penelitian tanaman padi. Subang hlm.02-23. 